
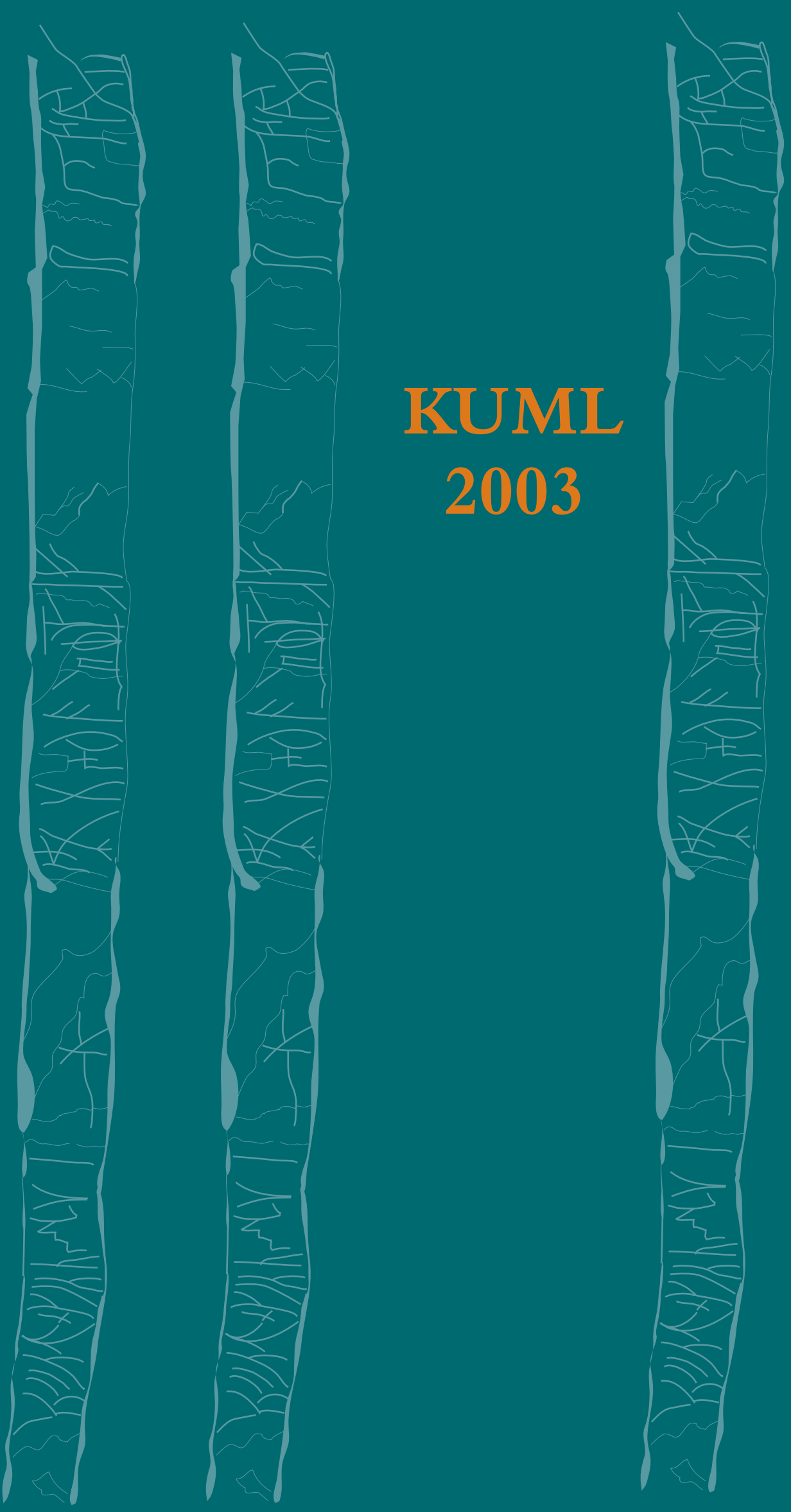


\section{KUML 2003}

Årbog for Jysk Arkæologisk Selskab

With summaries in English

I kommission hos Aarhus Universitetsforlag 


\title{
Til bords med Marsk Stig En oversigt over keramikken fra Hjelm
}

\author{
Af JETTE LINAA LARSEN
}

Skår af keramik er et af de almindeligste fund i næsten alle udgravninger af middelalderlige anlæg. Arbejdet med de mange skår kan være slidsomt, men har sine højdepunkter, og et af dem blev nået med fundene fra de senere års udgravninger på Hjelm.

Keramikken på Hjelm er kommet til i perioden mellem 1290, hvor borgene opførtes, og 1306 hvor Kong Erik Menved erobrede øen og brændte bebyggelsen ned. ${ }^{1}$ En undersøgelse af keramikken fra Hjelm er derfor vigtig af to grunde: for det første på grund af den personkreds, borgene kan knyttes til, for det andet på grund af borgenes præcise datering.

Det er kun sjældent, at der findes genstande, der kan knyttes til historisk kendte personer som Marsk Stig og hans mænd; de fleste arkæologiske genstande stammer fra personer, vi kun har lidt eller intet kendskab til. Samtidig kan keramikken yde sit bidrag til forståelsen af de fredløses stilling efter dommen i Nyborg 1287, da materiel kultur som keramikken kan være med til at vise, hvordan livsstilen på borgene var, og hvilke kontakter beboere havde til omverdenen. Bebyggelsen på øen havde en dobbeltfunktion som borge og som boliger for en række personer, hvoraf den mest kendte er den aristokratiske Marsk Stig. Fundet kan derfor være med til at belyse hans og hans mænds levemåde i en urolig tid.

Det for en arkæologisk betragtning korte åremål, som borgene var i brug (1290-1306), er en anden væsentlig grund til at undersøge brugsgenstandene, herunder keramikken, nærmere. Ved det korte åremål, 16 år, opnås noget af det nærmeste, vi som arkæologer kommer et snapshot af borgene $i$ brug. Mange andre borge har nemlig været $i$ brug $i$ en meget længere periode, og det er ikke altid let at afgøre, hvilke ting der er blevet anvendt samtidigt. Keramikken fra en veldateret lokalitet som Hjelm giver derfor et godt holdepunkt til datering af andre fund. Endelig er borgenes geografisk set isolerede beliggenhed med til at gøre dem til noget særligt. Der har således næppe været nogen transport af affald af betydning til og fra øen. Borgenes isolerede stilling i tid og rum er altså med til at gøre dem til et godt studiemiljø, hvor en række af de fejlkilder, der normalt gør forskningsresultaterne usikre, såsom opblanding af genstande fra ældre bebyggelser og indblanding af affald fra andre områder, kan lades ude af betragtning. 
For en middelalderlig betragter var keramikken et fleksibelt materiale til mange formål, og i husholdningen blev keramiske kar brugt til madlavning, opbevaring og transport og til servering, til at skænke op med og til at drikke af. Hertil kommer, at måltidet og samvær omkring bordet var en væsentlig ramme omkring middelalderens sociale liv som symbol på fællesskabet, for her foregik det, vi kender som familiemåltidet, forretningsmiddagene, receptionerne og festerne. Måltidets betydning i middelalderens samfundsliv fremgår da også af tidens billeder og beskrivelser af fester og banketter med mange deltagere og et stort antal retter. Keramik var naturligvis ikke det eneste materiale, som køkken- og bordtøj blev fremstillet af. Nogle ejede også sølvbægre, bronzegryder, jernkedler, tinkander og meget mere, som det ses i middelalderens skifter og testamenter. ${ }^{2}$ I arkæologiske fund giver metalkarrene dog ofte kun en svag forestilling om, hvad der har været, for ødelagte eller udtjente kar blev i stor udstrækning omsmeltet og genbrugt. Da keramikskår - derimod - ikke kan genbruges og heller ikke bliver nedbrudt, når de kommer i jorden, finder arkæologerne stort set al den keramik, som middelalderens mennesker smed ud på stedet, hvor vi graver.

\section{Keramik i Danmark omkring 1300}

Omkring 1300, i borgens tid, brugte man både danske og udenlandske kar. Vigtigst var de hjemlige glaserede kander, der kunne bruges til letøl, stærkt øl eller vin. Til madlavningen var indenlandske grå lertøjspotter uden glasur de mest almindelige. Potterne fandtes i mange størrelser; fra små eksemplarer, der indeholdt 1/2-1 liter, til store, bredbugede kogepotter, der kunne rumme mad til et helt folkehold. Kanderne og kogepotterne var højmiddelalderens »standardkøkkenudstyr". Der fandtes andre karformer - glaserede kogepotter, serveringsfade og småskåle og gråbrændte kander og skåle, men de ser ikke ud til at have været helt så almindelige.

Ved siden af den hjemlige keramik blev der brugt en del udenlandske kander. De mest almindelige var små kander og krus i meget hårdtbrændt ler, såkaldt næstenstentøj. Næstenstentøjet, der blev fremstillet flere steder i det nuværende Tyskland, udmærkede sig ved at være så godt som vandtæet, hvilket gjorde disse kander velegnede til at drikke af. Ved siden af næstenstentøjet blev franske og belgiske lertøjskander hovedsageligt brugt i byer, klostre og herregårde. Kanderne har navn efter produktionsstederne, hvoraf de vigtigste lå ved Saintonge ved Bordeaux, Rouen i Normandiet og Brügge i Belgien. Kanderne var porøse ligesom de hjemlige, men de var prægtige og farvestrålende, en pryd for ethvert måltid. Kanderne var forbilleder for de pottemagere, der fremstillede de hjemlige, 
glaserede kander. Hvor kanderne var farvestrålende, så var kogepotterne, som maden blev tilberedt i, udekorerede, grå og uden glasur. Skænkekanderne var meget synlige under gæstebud og gilder, mens kogepotterne levede en mere upåagtet tilværelse i køkkenregionerne. Dem var der ingen af gæsterne, der så.

\section{Keramikken fra Hjelm - en gennemgang}

Keramikken fra Hjelm omfatter 854 skår, der tilsammen vejer 6950 gram. Materialet er stort og velbevaret med store flager og mange stykker fra de enkelte kar. Samlet set er mængden af keramik fra Hjelm stor nok til, at man kan sige en del om, hvordan beboerne brugte keramikken, selvom fremtidige udgravninger selvfølgelig kan ændre billedet.

Størstedelen af keramikken blev fundet tre steder: på voldstederne Kastelsbakken og Fyrbakken, og på Møntværkstedet, der ligger i det åbne land nord for Kastelsbakken. Herudover fandt man enkelte skår af middelalderkeramik på fire lokaliteter i det åbne land (fig. 1). ${ }^{3}$ Foruden middelalderkeramikken blev der fundet et par skår af 17- og 1800-tals keramik på Hjelm. Disse skår, der sikkert er kommet til øen i forbindelse med, at den blev udnyttet til kvæggræsning i nyeste tid, skal ikke behandles nærmere her.

Det fremgår af fig. 1, at der kun er fundet ret få skår under udgravningerne, betydeligt færre end der findes ved de fleste udgravninger i byer. Det må skyldes, at beboelsen af øen kun varede kort, så store affaldsophobninger ikke nåede at blive dannet.

Det største fund, Møntværkstedet, har flest forskellige keramiktyper, hvilket også var at forvente rent statistisk. Hovedparten af skårene er af danskproduceret, blyglaseret og gråbrændt keramik, mens importeret keramik udgør en mindre, men markant del af fundet.

Det er vanskeligt at afgøre, hvor mange hele kar, skårene stammer fra. En optælling af randskårene viser, at der er skår fra mindst 10 glaserede og to gråbrændte kander, mens importen har omfattet mindst seks forskellige næstenstentøjskander, en kande fra Rouen og en kande fra Saintonge (fig. 2). Skårene fra de knuste kar er deponeret i affaldsgruber eller spredt omkring bebyggelsen, mens større oprydninger tilsyneladende er foregået ved, at man har kastet affald ud over skrænterne på øen. Det er en måde at omgås affald på, der ligner den, samtiden brugte i byerne. Her kørte man lejlighedsvis affaldet væk i vogne, når det blev for meget. En egentlig organiseret renovation hører en senere tid til. 


\begin{tabular}{|c|c|c|c|c|c|}
\hline Lokalitet & Keramiktype & Antal skår & Vægt (g) & Eve & Vægt(\%) \\
\hline \multirow[t]{4}{*}{ Fyrbakken } & Dansk blyglaseret keramik & 86 & 717 & 35 & 53,9 \\
\hline & Dansk gråbrændt keramik & 41 & 519 & 40 & 39 \\
\hline & Duingen & 9 & 94 & 0 & 7,1 \\
\hline & Sum & 136 & 1330 & 75 & 100 \\
\hline \multirow[t]{7}{*}{ Kastelbakken } & Dansk blyglaseret keramik & 197 & 1481 & 66 & 73,1 \\
\hline & Dansk gråbrændt keramik & 72 & 513 & 0 & 25,3 \\
\hline & Bengerode & 2 & 11 & 0 & 0,5 \\
\hline & Langerwehe type 1 & 1 & 7 & 0 & 0,3 \\
\hline & Langerwehe type 2 & 2 & 10 & 0 & 0,5 \\
\hline & Rouen & 2 & 5 & 0 & 0,2 \\
\hline & Sum & 276 & 2027 & 66 & 99,9 \\
\hline \multirow[t]{10}{*}{ Møntværkstedet } & Dansk blyglaseret keramik & 131 & 1274 & 127 & 40,6 \\
\hline & Dansk gråbrændt keramik & 214 & 1268 & 64 & 40,4 \\
\hline & Bengerode & 35 & 352 & 26 & 11,2 \\
\hline & Langerwehe type 1 & 10 & 101 & 0 & 3,2 \\
\hline & Langerwehe type 2 & 2 & 13 & 0 & 0,4 \\
\hline & Siegburg & 6 & 49 & 83 & 1,6 \\
\hline & Weser & 1 & 48 & 0 & 1,5 \\
\hline & Saintonge & 1 & 22 & 0 & 0,7 \\
\hline & Ukendt proveniens & 4 & 10 & 2 & 0,3 \\
\hline & Sum & 404 & 3137 & 302 & 99,9 \\
\hline \multirow[t]{4}{*}{ Øvrige fundsteder } & Dansk blyglaseret keramik & 16 & 317 & 14 & 69,5 \\
\hline & Dansk gråbrændt keramik & 18 & 131 & 8 & 28,7 \\
\hline & Langerwehe & 4 & 8 & 0 & 1,7 \\
\hline & Sum & 38 & 456 & 22 & 99,9 \\
\hline Total & & 854 & 6950 & 465 & \\
\hline
\end{tabular}

Fig. 1. Oversigt over keramikken fra fundsteder på Hjelm. Bemærk de mange forskellige typer af næstenstentøj, og at Møntværkstedet har mest keramik. Skårene er optalt som antal, vægt i gram og Eve. Eve (Estimated vessel equivalent) er et udtryk for, hvor mange procent af en hel mundingsrand, randskårene udgør.

A survey of the pottery found on the island of Hjelm. Note the numerous types of early stoneware and the fact that the majority of the potsherds were found in the "Mint" area. The sherds have been registered according to number, weight in grams, and Eve (Estimated vessel equivalent). Eve reflects the percentage of a complete rim made up by the rim sherds. 

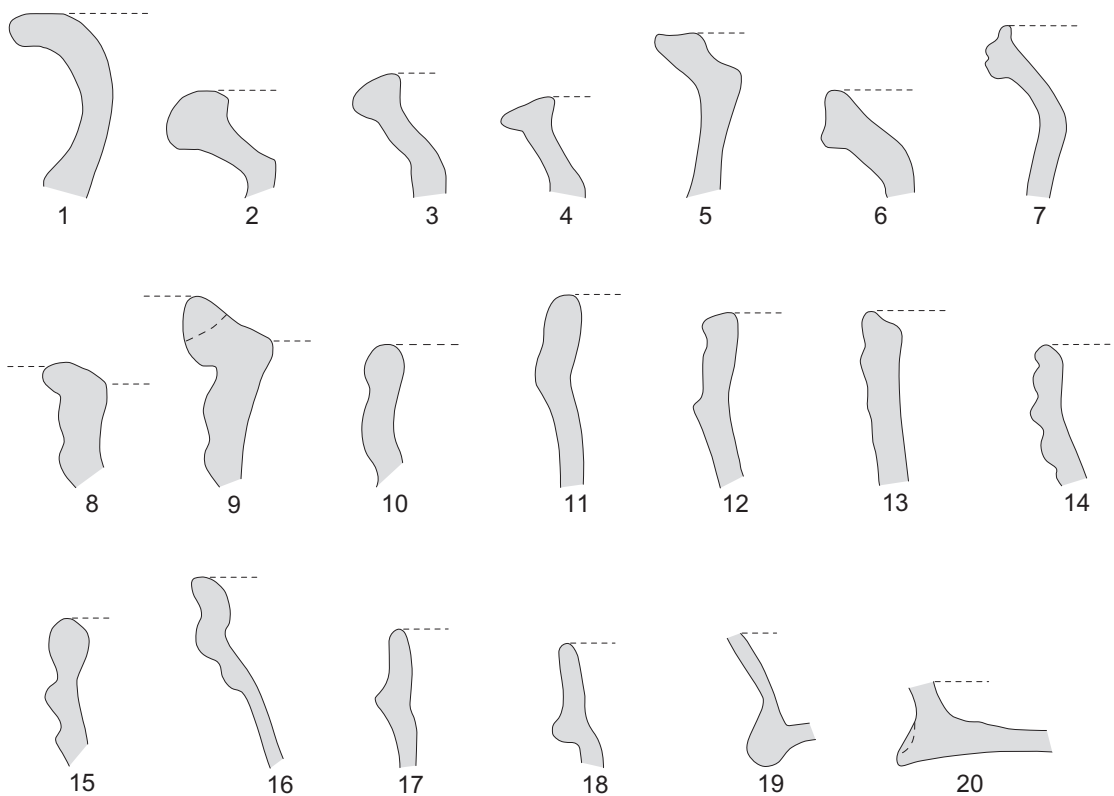

Fig. 2. Oversigt over randprofilerne fra Hjelm. 1-9: gråbrændt keramik, 10-16: blyglaseret keramik, 17-20: næstenstentøj. 1:2. - Tegning: Sven Kaae.

Types of the rim profiles from Hjelm. 1:2.

\section{Den danske keramik}

Det hjemlige lertøj blev formet på pottemagerhjul af det lokale rødler. Teknikken var lidt forskellig, alt efter om der skulle fremstilles kander eller kogepotter. Kanderne blev drejet op som en cylinder med markeret skulder, hals og rand og flad, afsat fod. Kandernes randpartier, der er mellem 7 og $12 \mathrm{~cm}$ i diameter, blev formet som en blødt svungen randlæbe med en eller to ribber på ydersiden og en skarpkantet liste på randens inderside. Halsene er slanke og oprette, og hældetuden er lille. Enkelte kander har dog halse, der er kraftigt indsnævrede forneden. Efter formningen af halspartiet blev cylinderens vægge banket ud til en hvælvet bug. Udbankningen, der har efterladt talrige mærker af pottemagerens knoer, var nødvendig, fordi pottemagerhjulet ikke kunne rotere hurtigt nok til, at det kunne lade sig gøre at dreje brede former. Kanderne har en s-formet profil, hvor kandens bredeste sted ligger midt på bugen. En enkelt kande har dog haft en klokkeformet profil; en form, der oftest ses i sjællandske fund. ${ }^{4}$ En anden kande er udført som en formmæssig efterligning af en stentøjskande; det ses af den flade fod med tydelige fingerindtryk, der er en klar stentøjsform. 
Fig. 3. Hanke, bund- og karvægsskår fra hjemlige glaserede kander. Bemærk de trinde hanke og karvægsskårenes dekorationer, der dels består af krydsende lister i lerets farve med skråsnit og hindbærknop i skæringspunktet, dels af mørkfarvede lister med en udflydende skælblomst.

- Foto: Preben Dehlholm.

Sherds from handles, bases, and bodies of glazed domestic jugs. Note the chubby handles and the decorations on the body sherds made up partly by criss-cross strips in the natural colour of the clay with slanting incisions and a 'raspberry' decoration in the intersection, partly by dark strips with a blurry scale flower.

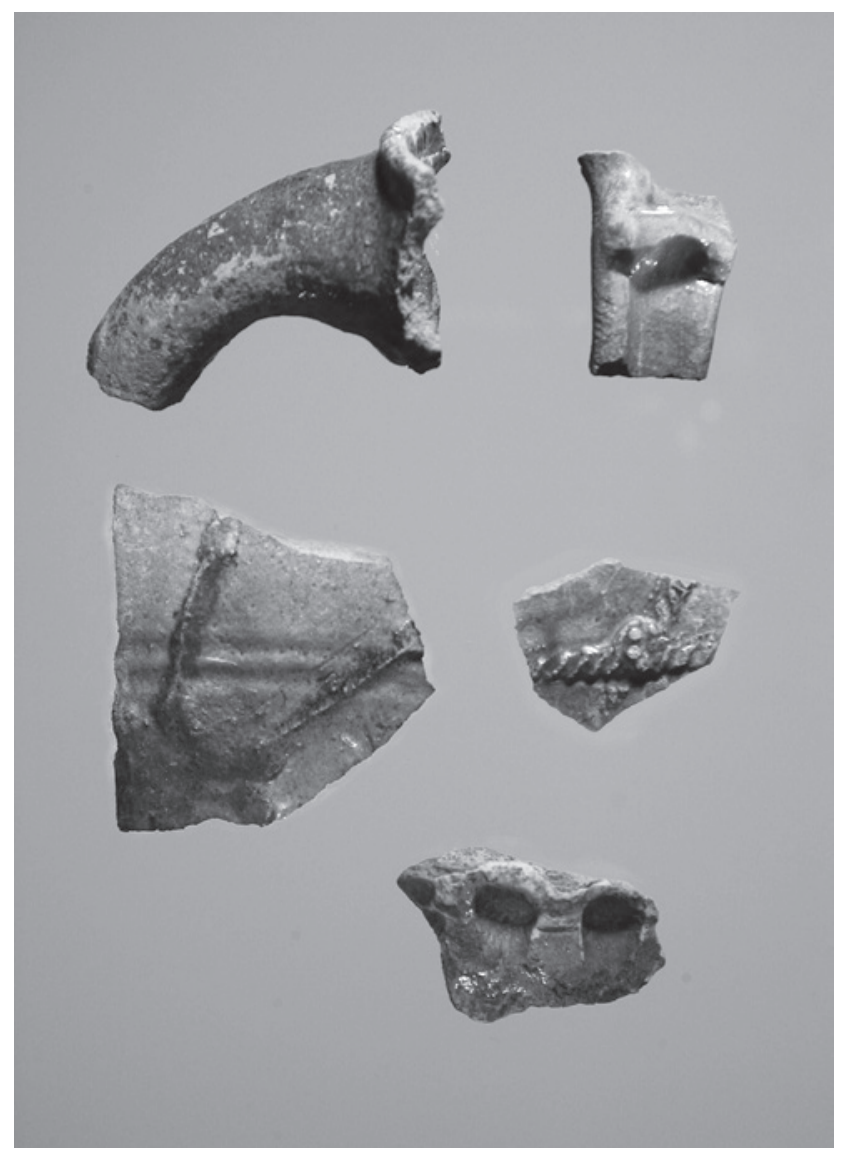

Hankene, der blev formet af en lerpølse, blev sat på lige under randen med et solidt tryk fra indersiden; et sted, hvor pottemagerens fingerindtryk ofte stadig ses. Hankene er enten trinde, båndformede eller D-formede. Fodrandene har en bølget kant, der er formet med små lodrette fingerindtryk. Ingen af kanderne er så velbevarede, at den oprindelige højde kan bestemmes, men andre fund viser, at kanderne oftest målte ca. $30 \mathrm{~cm} \mathrm{i}$ højden og kunne rumme et par liter. ${ }^{5}$ Skår fra en lille, blyglaseret skål viser, at kanderne ikke var ene om at repræsentere den blyglaserede keramik på øen. ${ }^{6}$ Ligesom kanderne er øens kogepotter også formet delvist på pottemagerhjulet, delvist $\mathrm{i}$ hånden. Her er randen, halsen og den øverste del af bugen drejet op af en lerklump på pottemagerhjul, mens bugen og den rundede bund er banket ud. Under drejningen er der formet en række dybe furer på skulder og hals. Enkelte kogepotter er formet helt i hånden, hvilket fremgår af den uregelmæssige inderside og en lamelagtig opbygning af skårenes brudflader. Disse potter er dekoreret med efterligninger 
af drejefurer på skulder og hals. Kogepotterne har alle udadbøjede rande. De fleste har en hulkehl på randens inderside, men enkelte har høj hals eller tre ribber på randlæben. Især de to første rande er almindeligt udbredte i det danske og skånske område omkring 1300.7 Kogepotterne er små, $12-16 \mathrm{~cm}$ i diameter ved randen, hvilket er ret småt i forhold til potter fra samtidige fund. ${ }^{8}$ Kogepotterne var ikke ene om at repræsentere den gråbrændte keramik. Der var også skår fra en bredmundet skål, $35 \mathrm{~cm} \mathrm{i}$ diameter, dekoreret med fingerindtryk på ydersiden af den kraftige, flade rand. Tilsvarende skåle er især almindelige i Østjylland, men dukker dog også op i fund fra det øvrige Jylland, Sjæelland og Skåne.

Efter formning blev karrene dekorerede. Kanderne fik den rigeste dekoration, der kunne være indpresset, formet af pålagt ler eller påmalet (fig. 3). Overgangen mellem hals og skulder blev markeret med enkelte og dobbelte furer eller vulster. Pålagte lister var den mest almindelige dekoration på bugen. Listerne havde fladt eller trekantet tværsnit, og nogle bestod af rækker af flade, dråbeformede skæl. Listerne var for det meste lagt på i et stort rude- eller netmønster på kandernes bug. I skæringspunkterne mellem listerne sad ofte en såkaldt hindbærknop; en enkronestor lerplade, der var stemplet, så den fik lighed med et hindbær. På nogle af listerne var der skåret skrå snit, der efterlignede en tovsnoning (fig. 4). Enkelte kander var
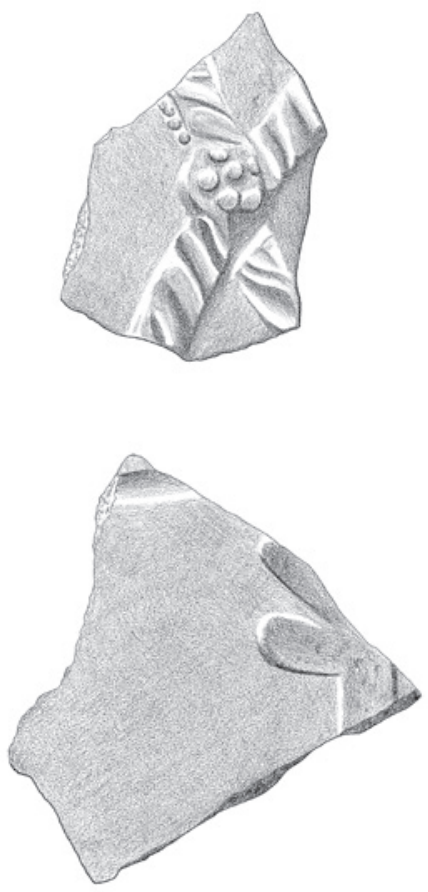

Fig. 4. Detalje af skår fra blyglaseret kande, dekoreret med et rudemønster af lister med skråhak, med en hindbærknop anbragt, hvor listerne krydser hinanden. 2:3. - Tegning: Louise Hilmar.

Detail of a lead glazed jug decorated with a diamond pattern made up by strips with slanting incisions and a 'raspberry' in the intersection. 2:3.

Fig. 5. Skår fra blyglaseret kande med rest af skælblomst. 2:3. - Tegning: Louise Hilmar.

A lead-glazed jug sherd with the remains of a scale flower. 2:3. 
dekorerede med skælblomster, med rækker af hindbærknopper eller med udflydende bemalinger, hvis form ikke længere kan bestemmes (fig. 5). Enkelte hanke var dekoreret; en med stempeldekoration på nederste fæste, en anden med en hvidlersbemalet ribbe. Den plastiske dekoration var malet i brune og gule farver med jernoxid eller hvidler. Bemaling med jernoxid var mere almindelig end bemaling med hvidler, men de to typer blev brugt på samme måde på lister, skæl og skælblomster (fig. 6).

Dekorationen på kanderne fra Hjelm har paralleller i en del, samtidige fund. Således kendes skælblomster, lister og hindbærknopper fra både Vestog Østjylland og fra Sjælland. ${ }^{10}$ Til gengæld er der en del dekorationsformer i samtidige fund, der ikke kan genfindes på Hjelm. Her er der hverken pindstik, hak, fingerindtryk eller bølgestreger, der er ret almindelige i Sydøstjylland, ligesom rullestemplede hanke, der er særligt karakteristiske i sjællandske fund, heller ikke forekommer på Hjelm. ${ }^{11}$ Om den tilsyneladende mangel på bestemte, ellers velkendte, dekorationer skyldes den snævre brugstid, leveringsforhold eller statiske forhold som følge af den ringe fundmængde, kan endnu ikke afgøres.

Efter dekoreringen blev kanden overdrysset med blypulver, der ved brænding smeltede sammen til en tynd glasur med nopret overflade. Glasuren dækkede oftest kandernes overdel, mens underdelen kun fik få glasurprikker. En del blypulver faldt gennem halsen og dækkede bundens inderside $i$ et mere eller mindre jæevnt lag. Glasuren var overvejende ment som en dekoration, for den blev påført så sparsomt og på så små partier, at tætning ikke kan have været hovedformålet.

Fig. 6. Oversigt over dekorationer på lokale, blyglaserede kandeskår fra

Hjelm. Bemærk, at manganbemalede, pålagte skæl og knopper er de mest almindelige dekorationer.

A survey of the decorations found on domestic lead-glazed jug sherds from Hjelm. Note that manganese painted, applied scales and knobs are the most ordinary decorations.

\begin{tabular}{|l|c|c|c|}
\hline & Manganmalet & Hvidler & Ufarvet \\
\hline Skælblomst & 2 & 1 & \\
\hline Skælliste & 7 & 4 & \\
\hline Anden liste & 5 & 1 & \\
\hline Pålagt knop & 8 & & \\
\hline Stribe & 3 & & \\
\hline Anden bemaling & 1 & 2 & \\
\hline Fure & & & 1 \\
\hline Dobbelt fure & 2 & 1 & 1 \\
\hline Stempel & & & 1 \\
\hline Udefinerbar & & & \\
\hline
\end{tabular}


Karrene blev brændt i en pottemagerovn ved ca. 800 grader. En åben ovn med fuld lufttilførsel anvendtes kun ved brænding af glaserede kander. Her blev uglaserede kardele røde, mens glaserede kar fik orangerød til rødbrun glasur. Hvis ovnens åbninger blev lukket under brændingen, så ilttilførsel blev forhindret, blev uglaserede kar grå eller sorte, og glasuren farvedes olivengrøn. En farvning af glasuren med metalforbindelser, som det kendes blandt andet fra sjellandske pottemagerovne, kan ikke genfindes på Hjelm. ${ }^{12}$ Brændingsprocessen var vanskelig. På nogle af kanderne er manganmalingen flydt ud, og andre har mange småsten i glasuren, hvilket forekommer, når et nærstående kar sprænges under brændingen. Der er ingen deformerede eller revnede kar på Hjelm, og i forhold til andre fund er der ret få beskadigede kar. Hvis man selv har brændt keramik på øen, fremgår det i alt fald ikke af det udgravede keramikmateriale.

Hvor kanderne fik en rig dekoration, var potterne oftest kun forsynet med vandrette furer på halsen. En undtagelse er en potte med indstemplet stjerne under randen. At stemplet har samme motiv som Marsk Stigs våbenskjold ligner en tanke, men stjernestemplet kendes fra så mange fund uden tilknytning til marsken, at der nok kun er tale om en tilfældighed. Stemplerne kendes fra samtidige fund i flere udformninger, cirkelkors, indtryk som sømhoveder, sparrer osv. og er en type, der fortsætter ind i 1400 -tallet. En potte er partielt glittet, en dekorationsform, der er udbredt i Østjylland, og især făr udbredelse med de langt senere jydepotter. ${ }^{13}$

\section{Den udenlandske keramik}

Blandt fundene fra Hjelm optræder skår af franske og tyske kander i en temmelig usædvanlig sammensætning (fig. 7). Mens de tyske kander er velbevarede med mange skår fra samme kar, er der kun bevaret ganske lidt af de franske kander.

Meget eksotiske er et par skår i hvidt ler med brun og grøn bemaling, der stammer fra en kande med motiver af fugle og blomster (fig. 8). Kanden er fremstillet ved byen Saintonge nær Bordeaux..$^{14}$ Af en mere udbredt type er et par kandeskår i hvidler med rød engobe og pålagte lister og knopper i hvidler, der lyser gult under blyglasuren. Skårene er fra kander, opkaldt efter byen Rouen i Normandiet, men der blev også fremstillet keramik med dette udseende omkring Paris. Om skårene er fremstillet i Rouen eller i Paris kan næppe afgøres uden tekniske undersøgelser. ${ }^{15}$

Det mest almindelige importerede bordtøj er drikke- og skænkekander af næstenstentøj. Næstenstentøj er benævnt således; den brændes ved temperaturer mellem 1050-1200 grader, hvorved skærven får ganske få porer og således næsten ligner det ægte, glasagtige stentøj. Næstenstentøj fremstilles af ler, der findes i Nordtyskland, men ikke i Danmark, og er derfor 
Fig. 7. Kort over hvor importkeramikken fra Hjelm er fremstillet. 1. Saintonge; 2. Rouen; 3. Langerwehe; 4. Siegburg; 5. Bengerode; 6. Duingen.

Map showing the origin of foreign pottery found on Hjelm. 1. Saintonge; 2. Rouen; 3. Langerwehe; 4. Siegburg; 5. Bengerode; 6. Duingen.

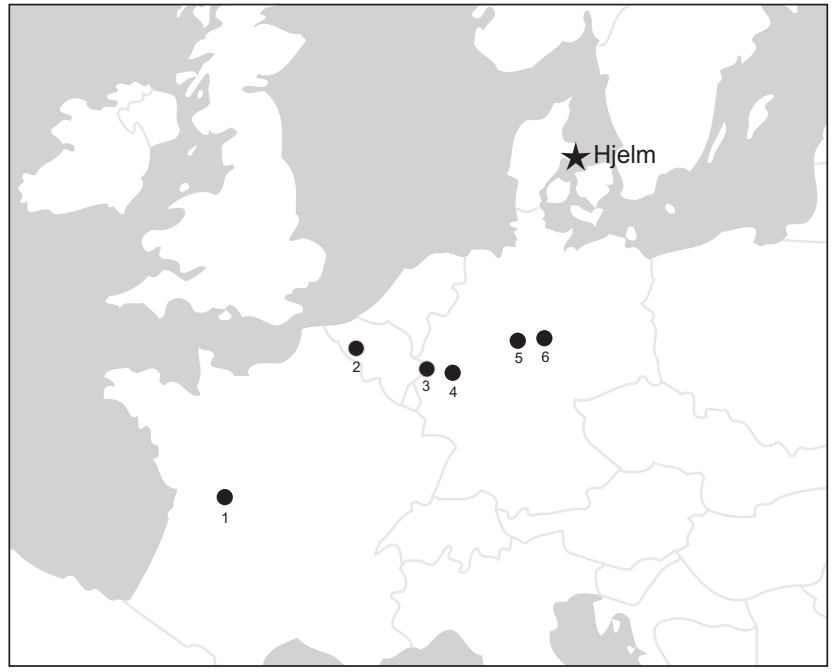

Fig. 8. Skår af hvidlerskande med flerfarvet bemaling, fremstillet i Saintonge nær Bordeaux. - Foto: Preben Dehlholm.

Sherds of a white fabric jug with polychrome painting, made in Saintonge near Bordeaux.

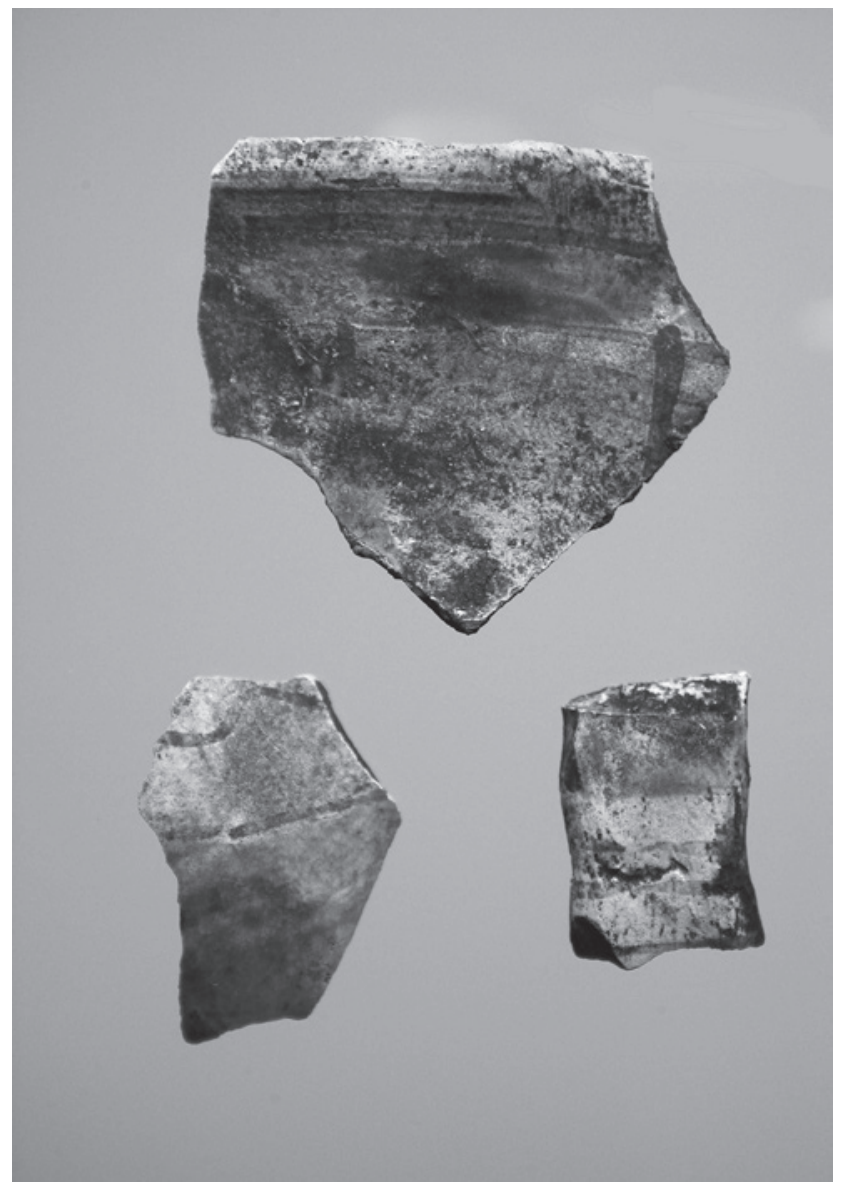


i middelalderen altid importeret. ${ }^{16}$ Produktionen af næstenstentøj, som det der er fundet på Hjelm, begyndte omkring midten af 1200-tallet. ${ }^{17}$

Næstenstentøjet fra Hjelm kommer fra mange forskellige steder, men kanderne er næsten ens, høje, slanke, drejede kander med bølgede fødder, vandrette riller på korpus, slanke halse med kraverand og spinkle hanke . Uglaserede partier er grå eller gule, og ydersiden har ofte jernholdig, matglinsende, grålig eller rødlig glasur, en såkaldt engobering. Bundene er $9 \mathrm{~cm}$ i diameter, og randene $5-7 \mathrm{~cm}$, så kanderne har været betydeligt mindre end de danske kander. Ingen kar kan sættes helt sammen, men helt bevarede kander af næstenstentøj er oftest 20-30 cm høje og rummer 1-2 liter.

Næstenstentøj blev fremstillet på en række pottemagerværksteder i det nordlige Tyskland, og mange af dem er repræsenteret på Hjelm. Mest iøjnefaldende er vinrøde kander med dobbelte flæser på korpus (fig. 9). Kanderne må være producerede i Bengerode - et pottemagercentrum nær Hannover, hvor der er fundet mange fejlbrændinger. ${ }^{18}$ Nogle lysegrå kander uden glasur med temmelig kornet skærv må være fremstillet i Siegburg ved Rhinen - det Siegburg, der senere skal få en meget stor produktion, og hvorfra meget af det stentøj, der er fundet i Danmark, stammer. ${ }^{19}$ Kander med karamelbrun glasur er sikkert fremstillet i Duingen - et pottemagercentrum i det nordlige Niedersachsen. Fra samme område, omkring flo-

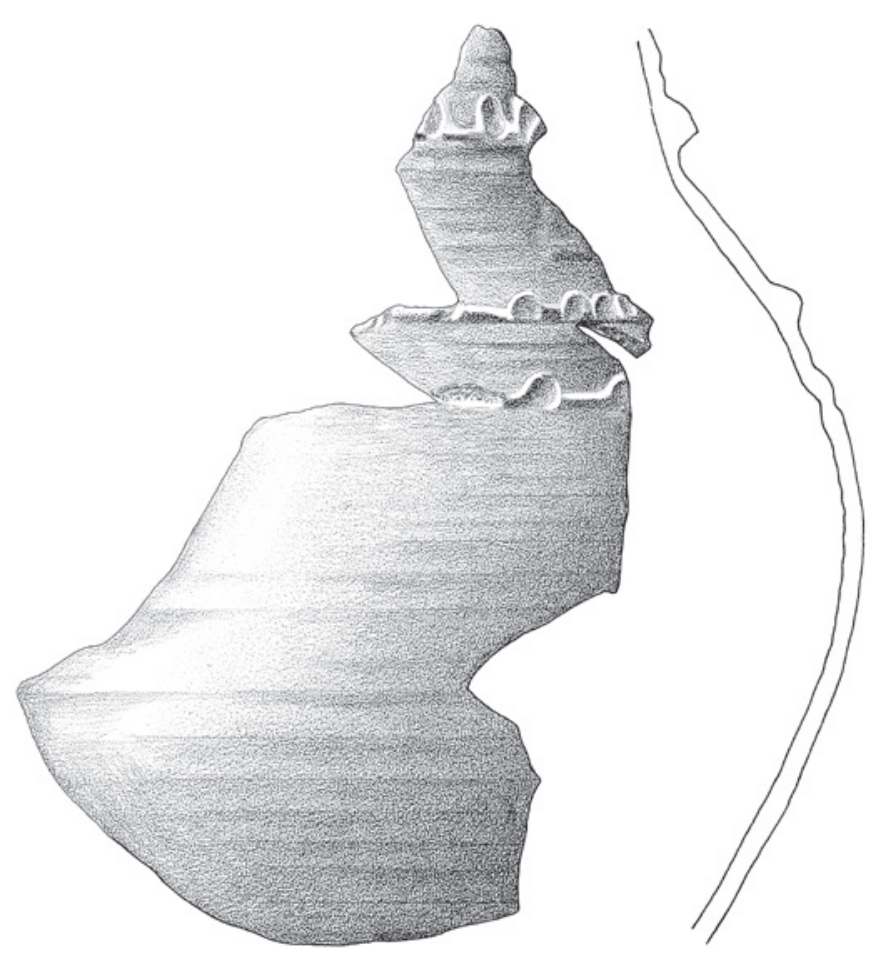

Fig. 9. Stort skår fra kande i næstenstentøj, fremstillet ved Bengerode $\mathrm{i}$ Hessen. Bemærk de pålagte lister med fingerindtryk. 1:2. - Tegning: Louise Hilmar.

A large sherd from an early stoneware jug made near Bengerode in Hesse. Note the applied thumbed strips. 1:2. 
Fig. 10. Bundskår af næstenstentøjskande. Den lille fod med utydelige fingerindtryk tyder på, at kanden er fremstillet ved Weserfloden i Hessen. 1:2. - Tegning: Louise Hilmar.

Base sherds from an early stoneware jug. The small base with indistinct thumb impressions indicates that the jug was made near the river Weser in Hesse. 1:2.

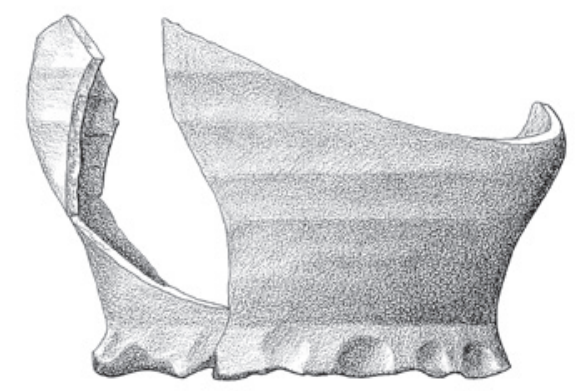

den Weser, stammer en lys rødbrun uglaseret kande med mørkere pletter (fig. 10). ${ }^{20}$ Endelig kommer en del keramik fra det rhinske produktionssted Langerwehe, kendelig på et smørgult gods, der er så blødt som lervare og en matviolet engobe. Nogle af skårene fra Langerwehe er hårdtbrændte, og da er leret gråt og glasuren brunlig. ${ }^{21}$

Udvalget af kander fra forskellige produktionssteder er imponerende. Det kunne tyde på, at kanderne er kommet til øen med skibstrafikken gennem Kattegat og Storebælt. Udvalget er i alt fald betydeligt større end det, der var til rådighed i de nærmeste købstæder, Århus og Horsens. ${ }^{22}$

En veldateret lokalitet som Hjelm kaster lys over keramikken omkring 1300. Først og fremmest bliver man slået af, at karrene er så ensartede. Kogepotterne har kun få forskellige rande, og de glaserede kander ligner hinanden med få forskellige hanke, bunde og rande. Det kunne tolkes i retning af, at der faktisk blev fremstillet potter og kander med få randformer samtidigt, men materialet er ikke stort, så man skal nok være forsigtig med at lægge for meget i det foreløbigt.

Man har gerne villet indsnævre den glaserede kandes dateringsmuligheder ved hjælp af dekorationen. Det er imidlertid næppe muligt, da det fremgår af skårene fra Hjelm, at mange af højmiddelalderens velkendte dekorationsformer har været i brug samtidig. Måske kan udformningen af kandehankene anvendes som et daterende element. Således er trinde hanke tidligere set som særligt gamle, mens hanke med flere kehlinger kunne være væsentligt yngre. ${ }^{23}$ Flerkehlede hanke ses da heller ikke blandt fundene fra Hjelm.

Importen har sin egen betydning, når talen falder på dateringerne, fordi importkeramik ofte optræeder med ret præcise tidsangivelser i udenlandske fund. Her må man dog huske på, at kanderne ikke nødvendigvis er brugt præcist samtidigt i Danmark og i udlandet. Kanderne fra Rouen og Saintonge dateres sædvanligvis til det sene 1200-tal og tidlige 1300-tal, hvilket passer udmærket med borgenes historiske datering. ${ }^{24}$ Det er tankevækkende, at der ikke findes et eneste skår af fuldt udviklet stentøj på borgen. Produktionen af det fuldt udviklede, gennemsintrede stentøj anses 
i almindelighed for at begynde lige efter 1300. De tidligste dateringer leveres af hollandske fund. Her er to møntskatte fra ca. 1290 nedlagt i kar af næstenstentøj, mens en anden møntskat blev nedlagt i et kar af ægte stentøj før 1333, men efter ca. 1310. ${ }^{25}$ I Danmark er ægte stentøj brugt som beholder for en møntskat, nedlagt efter 1352, mens en møntskat omkring 1285 blev nedlagt i en kande af næstenstentøj med samme randform som kanderne fra Hjelm. ${ }^{26}$ Disse dateringer stemmer overens med, at fundet på Hjelm, der er nedlagt før 1306, kun rummer næstenstentøj. Fraværet af xgte stentøj kunne således tyde på, at typen først introduceres i årtierne efter 1300, men her må de små mængder tages i betragtning. Der kan have været fuldsintret stentøj i omløb, uden at det er repræsenteret på Hjelm.

\section{Bordtøjets funktion og sociale signalværdi}

Keramikken omkring 1300 har til dels været lokalt præget. Hovedtyperne: den glaserede kande og den grå kogepotte har nok været de samme overalt, men forskelle i randformer, dekorationer og importens sammensætning ser ud til at afspejle en række mindre regioner - regioner, hvor lokale forhold som transportmuligheder og afsætningsforhold bestemte udbuddet. Præcise områder er endnu ikke fastlagt endeligt, men Vestjylland, Østjylland og det sjællandske område har nok udgjort særlige regioner med forskellig keramik. Indenfor hver region kan der have været mindre lokalområder, der blev forsynet med hjemlig keramik fra samme pottemagerværksted og med udenlandsk keramik fra samme importsted - købstad, havn eller lign. 1300-tallets pottemagerværksteder ligger hovedsageligt på landet i bekvem nærhed til det nødvendige brænde. En del pottemagerværksteder ligger nær borge og klostre, hvilket kan være et tegn på, at pottemageren, ved siden af en markedsbaseret handel i byerne, kunne basere sin produktion på en eller flere storaftagere. ${ }^{27}$

Keramikken fra Hjelm kommer tilsyneladende fra mere end ét pottemagerværksted. Mange af potterne og kanderne kan godt være lokale produkter, hentet på fastlandet mod vest, for de er tykvæggede og hårdtbrændte med mange store sten i leret, og minder meget om den keramik, der bliver fundet ved udgravninger på Djursland. De øvrige kar er finere i godset. Disse er næppe lokale produkter, men kunne stamme fra Århus, evt. fra Sjælland. Den klokkeformede kande kunne pege på Sjælland som oprindelsessted for en del af keramikken, men tilsvarende kander indgår også i inventaret i Århus by, så de har også kunnet skaffes her. ${ }^{28}$

Om keramikken fra Hjelm faktisk er fremstillet i Østjylland kunne måske afgøres ved kemiske analyser af lersammensætningen. Det er også teoretisk muligt, at keramikken er fremstillet på øen. Hvis de fredløse kunne bortføre kongens møntmester, kunne de nok også bortføre en pot- 
temager, men det er ikke særligt sandsynligt, at beboerne har dækket deres behov på den vis. Keramikfremstilling kræver en meget stor mængde brændsel, der næppe har været tilgængeligt i større mængder på den lille ø. At få brændslet udefra kunne meget vel vise sig at være en større opgave end at skaffe keramikken. Med tanke på beretningerne om uroligheder og anfald på de danske kyster, er det da en mulighed, at keramikken er kommet til ved ran, men den store volumen, store skrøbelighed og lave værdi i penge gør den ikke til et attraktivt bytte. Keramikken kan også være anskaffet ved fredelig handel. Man kunne vel i et eller andet omfang tage til fastlandet og købe forskellige fornødenheder der. Måske har man endda betalt med de mønter, man selv slog på øen. Det er heller ikke helt umuligt, at keramikken kan være leveret fra det jyske gods, der blev administreret udenom den danske konge. ${ }^{29}$ Det stemmer overens med, at noget af keramikken fra Hjelm ligner Djursland-keramik. At pottemagere kunne være fæstere hos en herremand kendes fra middelalderens England, og noget lignende kunne jo være tilfældet i Danmark, selvom jeg ikke kender danske kilder, der kan belyse forholdet. ${ }^{30}$

Den importerede keramik kunne, som tidligere omtalt, næppe købes i de nærmeste købstæder, for der er fundet mange typer på Hjelm, der endnu ikke er fundet i disse byer. ${ }^{31}$ Den kan i stedet være kommet til med skibstrafikken. I 1392 giver den norske konge privilegier på handelen på Hjelm til de meget betydende tyske handelsbyer Lübeck, Wismar og Stralsund. De tre byer kunne meget vel stå bag en del af leverancerne af næstenstentøj. Skriftlige kilder viser således, at hanseatiske købmænd var dybt involveret i handelen med stentøj i Nordtyskland. ${ }^{32}$

I middelalderen var anvendelsen af forskellige brugsgenstande både afhængigt af det lokale udbud, hvilken position køberen havde i lokalsamfundet, hvilke kontakter han havde, og hvad han havde råd til at betale. ${ }^{33}$ Keramikken fra Hjelm afviger fra andre samtidige fund på en række punkter. De franske kander fra Saintonge, et område der ofte sættes i forbindelse med vinhandel, er tilsyneladende ganske sjeldne. Kanderne er fundet på borgen Boringholm vest for Horsens, men optræeder tilsyneladende ikke blandt fundmaterialet fra en række andre 1300-tals voldsteder. ${ }^{34}$ Heller ikke i byfundene er typen udbredt i det danske område. Mere almindelige er kanderne fra Rouen, der kendes fra en del byer, klostre og borge. ${ }^{35} \mathrm{Næ}-$ stenstentøj er ret udbredt i danske fund fra 1200-tallet, men at der er så mange typer på øen er usædvanligt, og det peger på, at beboerne har haft endog meget gode muligheder for at skaffe eksotiske varer, hvilket vel skal ses i lyset af skibstrafikken til og fra øen.

Anvendelse af brugsgenstande som bord- og køkkentøj handler ikke kun om mad og drikke, men også om at demonstrere kultur og livsstil. Materiel kultur bliver hermed opfattet som en form for tingenes tavse sprog, der signalerer forbrugernes tilhør til bestemte samfundsgrupper, 
status, rigdom, religion eller politiske ideer. ${ }^{36}$ Genstandene spejler ejerens identitet, men ejeren kan også bruge bestemte ting til at efterligne livsstilen hos højere sociale lag og derved højne sin sociale status ved at manipulere omverdenens opfattelse af sig selv. ${ }^{37}$ Genstandene fra Hjelm kan forstås på denne baggrund. At dømme efter andelen af importkander og glaserede kander i det bevarede materiale, må forbruget af eksklusive kander til servering af drikkevarer have været betydeligt. $\mathrm{Nu}$ er mængderne fra Hjelm som sagt små og resultaterne derfor usikre, men noget tilsvarende kan ligeledes have været karakteristisk for andre borge. Andelen af importerede kander på øen ser også ud til at være noget højere end i den samtidige landbebyggelse. ${ }^{38}$ Det er da muligt, at importkeramikken, der ofte betragtes som ledsager til handel med vin eller øl, har rummet importerede drikkevarer på marskens bord. Keramikken giver altså indtryk af, at beboerne har opretholdt en eksklusiv, overklassepræget livsstil med væegt på repræsentation, selskabelighed og demonstration af hanseatisk præget levevis, den samme levevis, der spredte sig til stormænd og byernes øvre lag i det samme tidsrum og medførte ny mode, ny boligindretning og altså også nyt bordtøj. ${ }^{39}$ Det eksklusive bordtøj har nok hørt sammen med lige så eksklusive mad- og drikkevaner. Det stemmer overens med analyserne af øens knoglemateriale, der viser, at vildt som kanin og dådyr, der knytter sig til overklassens jagt, har været på menuen. ${ }^{40}$ Keramikken har naturligvis været et led i en større helhed, der omfatter bordtøj af træ og metal, dragtudstyr, smykker og våben. De øvrige brugsgenstande er endnu ikke bearbejdet i detaljer, men fundene omfatter en del genstande ud over det sædvanlige, blandt andet smykker, bogbeslag og dragtdetaljer af sølv. ${ }^{41}$ Brugen af det eksklusive bordtøj tyder på, at marsken og hans mænd fuldt ud var i stand til at opretholde en aristokratisk, internationalt orienteret levevis på den lille ø. Det ser således ud til, at konflikterne med den danske kongemagt ikke isolerede mændene på øen, for de må have haft mange kontakter både på fastlandet og ad søvejen for at skaffe keramikken. Tværtimod ser de ud til at have lagt megen vægt på at leve behageligt; en raffineret måde at vise styrke og overskud på i en urolig tid.

\section{NOTER}

1. Olsen 2002, s. $49 \mathrm{ff}$.

2. Hasse 1979; Linaa Larsen 2000.

3. Asingh \& Engberg 2002, s. 103ff; Asingh, Engberg \& Foged Klemensen 2002, s. 171ff; Engberg 2002, s. 157ff; Skov 2002, s. $133 f f$.

4. Andersen m.fl. 1971; Bencard \& Roesdahl 1972, nr. 52-3, 109-10.

5. Fremstilling af glaserede kander, se Nenk 1997.

6. Andersen m.fl. 1971; Bencard \& Roesdahl 1972; nr 96; Linaa Larsen 1997, s. 137.

7. Andersen m.fl. 1971; Augustsson 1985; la Cour 1961, s. 145; Liebgott 1979a, s. 63f; Lindahl 1986, s. 38f.; Madsen 1989; Wahlöö 1976, nr. 246, 316. 
8. Andersen m.fl. 1971, s. 89f.; Liebgott 1979, s. 64; Linaa Larsen 1997, bilag 14.

9. Andersen m.fl. 1971, s. 94; Hjermind 1997, s. 101; Lüdtke 1985, s. 47; Mårtensson 1976, s. 256.

10. Andersen m.fl. 1971; Bencard \& Roesdahl 1972; Madsen 1999, s. 114.

11. Andersen m.fl. 1971, s. 95; Bencard \& Roesdahl 1972; Linaa Larsen 1997.

12. Liebgott 1975.

13. Andersen m.fl. 1971, s. 95; Bencard \& Roesdahl 1979; Hjermind m.fl 1997, s. 107f; Linaa Larsen 1997.

14. Madsen \& Stilke 2001, s. 552ff.

15. Nicourt 1986, s. 119ff; Madsen \& Stilke 2001, s. 557ff.

16. Gaimster 1997b, s. 122ff; Müller 1996, s. 221.

17. Beckmann 1975; Reineking-von Bock 1971; Stephan 1988.

18. Grote 1976; Janssen 1966, s. taf. 20, abb. 14, 8; Roehmer 2001, s. 517ff; Stephan 1983.

19. Roehmer 2001, s. 471ff.

20. Roehmer 2001, s. 471ff.

21. Hurst 1977; Jürgens 1988; Roehmer 2001, s. 493ff; Stephan 1983.

22. Andersen m.fl. 1971; Gaimster 1997a; Linaa Larsen 1997.

23. Hjermind m.fl. 1997; Lüdtke 1985, s. 54f.

24. Allan 1983, s. 200f; Barton 1965; Hurst m.fl. 1986, s. 76f.

25. Janssen 1988; Roehmer 2001, s. 480; Sarfatij 1979, s. 499, nr. 3.

26. Liebgott 1978, s. 51f, 69. For stentøjets former se Beckmann 1975, taf. 20-21; Janssen 1988; Linaa Larsen 1997; Lüdtke 1985, s. 66-70, taf. 38-40; Stephan 1988, s. 96; Vince 1988, s. 242f.

27. Linaa Larsen 2000 , s. 198 f.

28. Andersen m.fl. 1971, s. $98 \mathrm{f}$.

29. Dansk Biografisk Leksikon 6, s. 631ff.

30. Nenk 1977, s. 91.

31. Andersen m.fl. 1971; Gaimster 1997a; Linaa Larsen 1997.

32. Hørby 1989, s. 154; Gaimster 1997a, s. 64ff.

33. Elfwendahl 1999; Courtney 1997; Gaimster 1997; Madsen 1992; Linaa Larsen 2000, s. 205ff; Verhaeghe 1999.

34. Tak til ph.d.-studerende Charlotte Boje Andersen, Nationalmuseet, for oplysninger om fund af Saintonge på danske borganlæg. Se også Boje Nielsen 1999, s. 18 f og Madsen \& Stilke 2001, s. 557ff.

35. Andersen m.fl. 1971; Hjermind m.fl. 1997, s. 115; Linaa Larsen 1997; Madsen 1999, s. 76; Madsen \& Stilke 2001, s. 552ff.

36. Wobst 1977, s. 327.

37. Shanks \& Tilley, s. 140ff; Hodder 1986, s. 6.

38. Linaa Larsen 2003(i tryk); Linaa Larsen 2000, s. $205 \mathrm{ff}$.

39. Gaimster 1997, s. 126ff; Hasse 1979.

40. Enghoff 2002, s. $221 \mathrm{ff}$.

41. Skov 2002, s. 153-4; Asingh, Engberg \& Foged Klemensen 2002, s. 191.

\section{LITTERATUR}

Allan, J. 1983: The Importation of pottery to south-west England. 1200-1500. I: P.R. Davey $\&$ R. Hodges (eds.): The production and distribution of later medieval pottery in north-west Europe. Sheffields.

Andersen, H.H., P.J. Crabb \& H.J. Madsen 1971: Århus Søndervold - en byarkceologisk undersøgelse, Jysk Arkæologisk Selskabs Skrifter I. Højbjerg. 
Asingh, P. \& N. Engberg 2002: Fyrbakken. I: P. Asingh \& N. Engberg (red.): Marsk Stig og de fredløse på Hjelm. Højbjerg, s. 103-131.

Asingh, P., N. Engberg \& M. Foged Klemensen 2002: Det åbne land mellem voldstederne. I: P. Asingh \& N. Engberg (red.): Marsk Stig og de fredløse på Hjelm. Højbjerg, s. 171-201.

Asingh P. \& N. Engberg (red.) 2002: Marsk Stig og de fredløse på Hjelm. Jysk Arkæologisk Selskabs Skrifter 40. Højbjerg.

Augustsson, J.-E. 1985: Keramik i Halmstad ca. 1322-1619. Produktion - Distribution - Funktion. Lund.

Barton, K.J. 1965: Medieval Pottery at Rouen. Archaeological Journal CXII, s. 73-85.

Beckmann, B. 1976: Der Scherbenhügel in der Siegburger Aulgasse I. Rheinischer Ausgrabungen 16. Bonn.

Bencard, M. \& E. Roesdahl 1972: Dansk Middelalderlertøj 1050-1550. Jysk Arkæologisk Selskabs Håndbøger I. Højbjerg.

Boje Nielsen, C. 1999: Livet på en 1300-tals borg. 1066. Tidsskrift for historie, nr. 1, s. 15-23.

la Cour, V. 1961: Nosholm. København.

Courtney, P. 1997: Ceramics and the History of Consumption: Pitfalls and prospects. Medieval ceramics 21, s. 69-72.

Dansk Biografisk Leksikon, 3. udgave, bd. 6, København 1980, s. $631 \mathrm{ff}$.

Elfwendahl, M. 1999: Från skärva til kärl. Ett bidrag til vardagslivets historia i Uppsal. Lund Studies in Medieval Archaeology 22. Lund.

Engberg, N. 2002: Skådebakken. I: P. Asingh \& N. Engberg (red.): Marsk Stig og de fredløse på Hjelm. Højbjerg, s. 157-169.

Enghoff, I.B. 2002: De fredløses måltider. I: P. Asingh \& N. Engberg (red.): Marsk Stig og de fredløse på Hjelm. Højbjerg, s. 221-243.

Gaimster, D.R.M. 1997a: German Stoneware 1200-1900: Archaeology and Cultural History. London.

Gaimster, D.R.M. 1997b: Stoneware Production in Medieval and Early Modern Germany. I: Ian Freestone \& David Gaimster (eds.): Pottery in the Making. World Ceramic Traditions, London, s. 122-27.

Grote, K. 1976: Bengerode, ein spätmittelalterlicher Töpferort bei Fredesloh in südlichen Niedersachsen. Nachrichten aus Niedersachsens Urgeschichte 45, s. 245-304.

Hasse, M. 1979: Neues Hausgerät, neue Häuser, neue Kleider - eine Betrachtung der städtischen Kultur im 13. und 14. Jahrhundert sowie ein Katalog der metallenden Hausgeräte. Zeitschrift für Archäologie des Mittelalters 7, s. 7-83.

Hjermind, J., M. Iversen \& H. Krongaard Kristensen 1998: Viborg Søndersø 1000-1300: Byarkcologiske undersøgelser 1981 og 1984-85, Viborg Stiftsmuseums skriftrække 2 - Jysk Arkæologisk Selskabs skrifter IV. Højbjerg.

Hodder, I. 1982: Symbols in Action. Cambridge.

Hurst, J.G. 1977: Langerwehe Stoneware of the Fourteenth and Fifteenth centuries. I: M.R.R. Apted, R. Gilyard-Beer \& A.D. Saunders (eds.): Ancient monuments and their interpretation. Essays presentet to A.J. Taylor. London /Chicester, s. 219-38.

Hurst, J.G., D.S. Neal \& H.J.E. Van Beuningen (eds.) 1986: Pottery produced and traded in northwest Europe 1350-1650. Rotterdam Papers VI. Rotterdam.

Hurst, J.G. 1988: Problems of Middle-Rheinish stoneware in Britain. I: D.R.M. Gaimster, M. Redknap \& H-H. Wegner (eds.): Zur Keramik des Mittelalters und der beginnende Neuzeit im Rheinland/Medieval and later pottery from the Rhineland and its markets. Bar International Series 440. Oxford, s. 335-42.

Hørby, Kai 1989: Velstands krise og tusind baghold 1250-1400, Gyldendal og Politikens Danmarkshistorie (red. Olaf Olsen), bd. 5. København.

Janssen, H.L. 1983: Late medieval pottery production in the Netherlands. I: P.R. Davey \& R. 
Hodges (eds.): Ceramics and trade. The production and distribution of later medieval pottery in north-west Europe. Sheffield, s. 121-85.

Janssen, H.L. 1988: The dating and typology of the earliest Siegburg Stoneware in the Netherlands. I: D.R.M. Gaimster, M. Redknap \& H-H. Wegner (eds.): Zur Keramik des Mittelalters und der beginnende Neuzeit im Rheinland/Medieval and later pottery from the Rhineland and its markets. Bar International Series 440. Oxford, s. 311-24.

Janssen, W. 1966: Zur Typologie und Chronologie mittelalterlicher Keramik aus Südniedersachsen. Göttinger Schriften zur Vor- und Frühgeschichte 7. Neumünster.

Jürgens, A. 1988: Langerwehe-Brühl-Frechen: Neue Grabungen und Erkentnisse in Rheinischen Töpfereizentren. I: D.R.M. Gaimster, M. Redknap \& H-H. Wegner (eds.): Zur Keramik des Mittelalters und der beginnende Neuzeit im Rheinland/Medieval and later pottery from the Rhineland and its markets. Bar International Series 440. Oxford, s. 125-50.

Jørgensen, L.I. 2002: Kongemorder og adelshelt. I: P. Asingh \& N. Engberg (red.): Marsk Stig og de fredløse på Hjelm. Højbjerg, s. 75-101.

Liebgott, N.-K. 1975: Medieval Pottery Kilns at Faurholm in North Zealand, Denmark. Acta Archaeologica 46, s. 95-118.

Liebgott, N.-K. 1978: Danske fund af møntdateret keramik ca. 950-1450. Nationalmuseets Skrifter. Arkæologisk-historisk række VIII. København.

Liebgott, N.-K. 1979: Stakhaven. Arkceologiske undersøgelser i senmiddelalderens Dragør. Nationalmuseets Skrifter. Arkæologisk-historisk række I. København.

Lindahl, A. 1986: Information through sherds: a case study of the early glazed earthenware from Dalby, Scania. Lund Studies in Medieval Archaeology 3. Lund.

Linaa Larsen, J. 1997: Keramik fra Torvet i Horsens - Typologi, proveniensbestemmelse og datering. Højbjerg.

Linaa Larsen, J. 2002: Kar i hvermands eje - køkken-og bordtøjets brug og betydning i senmiddelalder og renassance. Aarhus (utrykt ph-d.-afhandling ved Aarhus Universitet).

Linaa Larsen, J. 2003: Genstandsfundene. Tonderhus (red. L.S. Madsen) (under udgivelse).

Lüdtke, H. 1985: Die Mittelalterliche Keramik von Schleswig. Ausgrabung Schild 1971-1975. Ausgrabungen in Schleswig. Berichte und Studien 4.

Lüdtke, H. \& K. Schietzel (hrsg.) 2001: Handbuch zur mittelalterlichen Keramik in Nordeuropa bd. 1-3. Neumünster.

Madsen, P.K. 1989: Handelskeramik fra middelalderens Grønnegade. By, marsk og geest 2, s. 243-58.

Madsen. P.K. 1992: Byarkæologiens genstandsfund. Kilder til handels- og innovationshistorie, socialtopografiske ledetyper eller blot dagliglivets tilfældige affald?. I: P. Ingesmann og J.V. Jensen (red.): Danmark i senmiddelalderen. Århus, s. 259-81.

Madsen, P.K. (red.) 1999: Middelalderkeramik fra Ribe: Byarkoologiske undersøgelser 1980-87. Den antikvariske Samlings skriftrække 2, Jysk Arkæologisk Selskab, Højbjerg.

Madsen, P.K. \& H. Stilke 2001: Bleiglasierte Irdenware. I: H. Lüdtke \& K. Schietzel (hrsg.): Handbuch zur mittelalterlichen Keramik in Nordeuropa bd.1-3. Neumünster, s. 539-611.

Moorhouse, S. 1983: Documentary Evidence and its Potential for Understanding the Inland Movement of Medieval Pottery. Medieval Ceramics 7, s. 45-88.

Müller, U. 1996: Die Keramikfunde der archäologischen Untersuchungen im Handwerkerviertel zu Lübeck. Lübecker Schriften zur Archäologie und Kulturgeschichte 24, s. 53-214.

Mårtensson, A.W. 1976: Uppgrävt förflutet för PK-banken i Lund. En investering $i$ arkeologi, Archaeologica Lundensia VII. Malmö.

Nenk, B. 1997: Highly Decorated Pottery in Medieval England. I: Ian Freestone \& David Gaimster (eds.): Pottery in the Making. World Ceramic Traditions. London, s. 92-97.

Nicourt, J. 1986: Céramiques Médiévales parisiennes. Classification et typologie. Ermont.

Olsen, R.A. 2002: Den historiske Marsk Stig og Hjelm. I: P. Asingh \& N. Engberg (red.): Marsk Stig og de fredløse på Hjelm. Højbjerg, s. 49-73. 
Reineking-von Bock, G. 1971: Steinzeug, Kataloge des Kunstgewerbemuseums Köln IV. Köln.

Roehmer, M. 2001: Steinzeug. I: H. Lüdtke \& K. Schietzel (hrsg): Handbuch zur mittelalterlichen Keramik in Nordeuropa. Neumünster, s. 465-538.

Sarfatij, H. 1979: Münzschatsgefässe in der Niederlanden I: Die Periode 1190-1566. Berichte Amersfoort 29, s. 491-526.

Shanks, M. \& C. Tilley 1987: Social Theory and Archaeology. Oxford.

Skov, H. 2002: Kastelsbakken. I: P. Asingh \& N. Engberg (red.): Markk Stig og de fredløse på Hjelm. Højbjerg, s. 133-155.

Stephan, H.-G. 1983: The development and production of medieval Stoneware in Germany. I: P.R. Davey \& R. Hodges (eds.): Ceramics and trade. The production and distribution of later medieval pottery in north-west Europe. Sheffield, s. 65-122.

Stephan, H.-G. 1988: Diskussionsbeitrag zur Abgrenzung und definition mittelalterlicher deutscher Steinzeuggruppen. I: D.R.M. Gaimster, M. Redknap \& H-H. Wegner (eds.): Zur Keramik des Mittelalters und der beginnende Neuzeit im Rheinland/Medieval and later pottery from the Rhineland and its markets. Bar International Series 440. Oxford, s. 81-118.

Verhaeghe, F. 1999: Trade in ceramics in the North Sea region, 12th to 15th centuries: A methodological problem and a few pionters. Lübecker Kolloquium zur Stadtarchäologie im Hanseraum II: Der Handel, s. 139-168.

Vince, A. 1988: The date and frequency of German imports in the City of London from the 10th. to the 15th. Century. I: D.R.M. Gaimster, M. Redknap \& H-H. Wegner (eds.): Zur Keramik des Mittelalters und der beginnende Neuzeit im Rheinland/Medieval and later pottery from the Rhineland and its markets. Bar International Series 440. Oxford, s. 241-42.

Wahlöö, C. 1976: Keramik 1000-1600 i svenska fynd. Archaeologica Lundensia VI. Lund.

Wobst, H.M. 1977: Stylistic behavior and information exchange. Anthropological Papers 61. Michigan, s. 317-342. 


\section{Dining with Marsk Stig}

\section{A survey of the Hjelm pottery}

Potsherds occur frequently in nearly every excavation of a medieval settlement. Working with this abundance of sherds is usually a laborious job, but it is sometimes very rewarding. This was the case when during recent years the small island of Hjelm off the east coast of Jutland was excavated. The Hjelm excavation was published in 2002. However, the pottery is interesting enough to deserve special treatment.

The Hjelm pottery stems from the period between 1290, when the castles on Hjelm were built, and 1306, when King Erik Menved captured the island and burnt down the settlement. Consequently, an examination of the Hjelm pottery is important for two reasons: Firstly, because the castles were connected to a certain class, and secondly, because they had a very short lifetime. The amount of pottery found on Hjelm is not large. In all, 854 sherds were found during the excavations of Fyrbakken (the Lighthouse Hill), Kastelbakken (the Citadel Hill), Møntværkstedet (the Mint), and certain areas in the open landscape (fig. 1). The pottery finds consist of glazed jugs for the table, unglazed, grey cooking pots, and a number of colourful, imported jugs for serving and drinking.
There are relatively few rim types represented, which may be due to the short lifetime of the castles (fig. 2). The glazed jugs have a plastic decoration of strips, scales, or 'raspberries' - all known from a number of other finds (figs. 3, 4, 5, and 6). A visual examination of the fabric indicates that the majority of the domestic pottery was made by potters on the Djursland peninsula. Apart from the domestic pottery, there is a considerable amount of imported white fabric jugs and early stoneware (fig.7), such as polychrome white fabric jugs from Rouen and Saintonge (fig. 8) and early stoneware jugs made in the Rhine and Weser areas (figs. 9 and 10). In view of the dating of the castles, it is interesting that only early stoneware occurs on the island, whereas completely sintered stoneware is absent. This indicates that 'proper' stoneware did not reach the area until the early $14^{\text {th }}$ century. The variation within the imported pottery is considerable, with pottery from many different places of origin. This suggests that Marsk Stig (Lord High Constable Stig Andersen) and his men attached importance to the maintenance of a cosmopolitan lifestyle with an emphasis on the pleasures of the table, on status, and on demonstrating power.

Jette Linaa Larsen Moesgård Museum

Translated by Annette Lerche Trolle 